\title{
Letter to the Editor: Regarding a possible non-null interpretation of the Michelson-Morley experiment
}

Maurizio Consoli

Istituto Nazionale di Fisica Nucleare, Sezione di Catania, Italy

Follow this and additional works at: https://digitalcommons.wayne.edu/jmasm

Part of the Applied Statistics Commons, Social and Behavioral Sciences Commons, and the Statistical Theory Commons

\section{Recommended Citation}

Consoli, M. (2018). Letter to the Editor: Regarding a possible non-null interpretation of the Michelson-Morley experiment. Journal of Modern Applied Statistical Methods, 17(1), eP2922. doi: 10.22237/jmasm/1525132860

This Letter to the Editor is brought to you for free and open access by the Open Access Journals at DigitalCommons@WayneState. It has been accepted for inclusion in Journal of Modern Applied Statistical Methods by an authorized editor of DigitalCommons@WayneState. 


\title{
Letter to the Editor: Regarding a possible non-null interpretation of the Michelson- Morley experiment
}

\author{
Maurizio Consoli \\ Istituto Nazionale di Fisica Nucleare \\ Catania, Italy
}

\section{Letter to the Editor}

After discovering your interest for a possible non-null interpretation of the Michelson-Morley experiment (Sawilowsky, 2003; Sawilowsky, 2005), I would kindly draw your attention to Consoli and Pluchino (2018; see cited references on the same subject).

Your observation is correct. There is a definite statistical significance in the data. Therefore, by changing the theoretical framework, the small irregular residuals can acquire a definite physical meaning. In our interpretation, they seem to represent the first experimental indication for the earth motion within the Cosmic Microwave Background.

\section{References}

Consoli, M., \& Pluchino, A. (2018, January 9). Detecting the CMB dipole within the earth laboratory. arXiv:1801.03775 (physics.gen-ph). Retrieved from https://arxiv.org/abs/1801.03775

Sawilowsky, S. S. (2003). Deconstructing the arguments from the case against hypothesis testing. Journal of Modern Applied Statistical Methods, 2(2), 467-474. DOI: 10.22237/jmasm/1067645940

Sawilowsky, S. S. (2005). Letter to the Editor: Abelson's paradox and the Michelson-Morley experiment. Journal of Modern Applied Statistical Methods, 4(1), 352. DOI: 10.22237/jmasm/1114907520

doi: 10.22237/jmasm/1525132860 | Accepted: March 21, 2018; Published: June 7, 2018.

Correspondence: Maurizio Consoli, maurizio.consoli@ct.infn.it 